\title{
US Congress adds its voice to the genome-sequencing chorus
}

\section{Washington}

If Senator Pete Domenici (Republican, New Mexico) has his way, US law will require that the human genome be mapped and sequenced as rapidly as possible. But it became clear last week during hearings on a bill introduced by Domenici that the federal agencies most likely to be involved in the project, although pleased by the senator's interest, have grave reservations about his legislation.

Domenici's bill is intended to improve relations between universities and private industry on the one hand and US national laboratories on the other to speed development of technology "in energy areas of significant economic potential". In addition to the genome project, the bill would create superconductivity research centres at national laboratories, a semiconductor manufacturing initiative and a group of entrepreneurial institutes.

Acting director of the office of energy research James Decker said his agency opposes the bill as written, arguing that the superconductivity centres would be allowed to spend money without Energy Department approval. Presidential science advisor William Graham added that the White House considers the legislation of superconductivity unnecessary, because the president has already issued a directive supporting such research.

A primary goal of Domenici's bill is to improve US economic competitiveness. Using this argument, Domenici nearly succeeded in attaching his bill to a trade bill that was eventually passed by the senate. Representative Manuel Lujan (Republican, New Mexico), recently sponsored a bill in the House of Representatives identical to Dominici's bill.

The bill has sparked concern at the National Institutes of Health (NIH). As the debate over how and whether the human genome should be mapped and sequenced has proceeded over the past 18 months, there have been jealousies among government agencies about who should lead the project. The Energy Department first discussed the mapping and sequencing project in February 1986 but soon NIH, the National Science Foundation and private research organizations entered the debate.

The Energy Department has a specific line item in its budget for its genome efforts. Energy Secretary James Herrington even issued a press release last week announcing that specific centres for the project had been created at the department's Los Alamos and Lawrence Livermore National Laboratories. But NIH Director James Wyngaarden has let it be known that NIH considers it presump- tuous for the Energy Department to lay claim to lead agency status. Energy will spend \$12 million on mapping and sequencing efforts this year, whereas Wyngaarden calculates that NIH spends $\$ 300$ million annually on related research.

Last week Domenici sought to reassure Wyngaarden that he has no intention of shutting NIH out of the project. He even offered to change the title of the bill to the NIH Cooperative Research Initiative if it would make Wyngaarden better disposed towards it.

Domenici's questions to the panel of scientists and industry representatives

$$
\begin{aligned}
& \text { But there Must be a gene for } \\
& \text { Presidential Material... }
\end{aligned}
$$

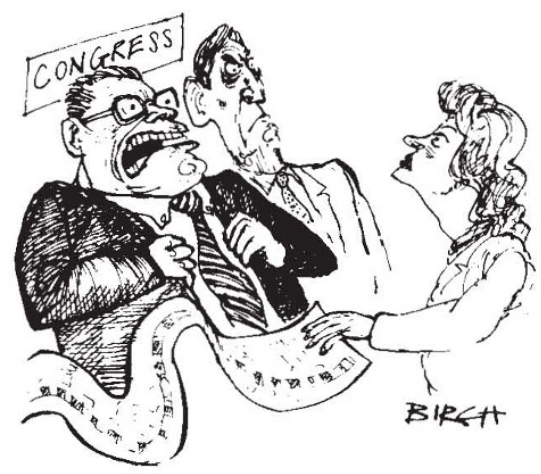

testifying at the hearing centred on what specific benefits sequencing the human genome would have for US competitiveness in high technology. The industry spokesmen said they were primarily interested in the project from an engineering standpoint, and would seek first refusal to any patentable processes of inventions to come out of the effort. But Patricia Postma, a technology-transfer specialist, said new technologies emerging from national laboratories are likely to be way ahead of their potential markets, forming a barrier to commercialization.

Last week's hearing became unusually spirited, as Domenici seemed to be playing the role of prosecuting attorney, crossexamining Wyngaarden and Decker. Domenici tried to make them admit that the genome project would be more certain to proceed if there was legislation making it a national policy to do so. But Wyngaarden retorted that plenty of biomedical research is accomplished without the benefit of a specific national policy.

Wyngaarden and Decker seem to think the Domenici bill unnecessary, and that coordination of federal activities can come from a subcommittee of the White House Domestic Policy Council that Wyngaarden chairs. Joseph Palca \& Carol Ezzell

\section{Theory never to be practice?}

Ithaca, New York

CORNELL University was naturally pleased to receive a pledge of $\$ 10$ million from the state of New York to build a new home for the Theory Center - Cornell's national centre for advanced scientific computing. But plans have hit a snag. The proposed building cuts into the tree line above one of Ithaca's famous gorges. Opponents have launched a campaign to block construction at the proposed site, throwing the university's plans to modernize its engineering campus into turmoil.

The Theory Center is one of the five national supercomputer facilities supported by the National Science Foundation (NSF). But as university officials hasten to point out, it is the only one without its own building. Theory Center staff are at present in temporary quarters in the chemical engineering building.

Crowded and antiquated facilities on the engineering campus have been particularly taxed by Cornell's success in attracting research funding. Cornell vicepresident John Burness says the university leads the country in research awards from NSF, and research spending by the engineering faculty has increased nearly eightfold in the past decade.

But the engineering 'quad' is virtually out of space. The university thought it had found a solution by building on a parking lot behind the quad. But the structure, designed by Robert Siegel of GwathmeySiegel of New York, did not end at the parking-lot boundary - it stretched into the gorge cut by Cascadilla Creek. Burness says the university "goofed" by not realizing this from the start.

The university ordered modifications, bringing the building closer to the parking lot. But even in its modified form, a blue ribbon marking the site of a retaining wall on one side of the building cuts through a stand of trees that marks the edge of the gorge. This is despite a promise made in 1972 by the university regents not to build into the gorges, and complaints were aired at a public hearing held on 17 August.

Burness rejects criticism that the university has not planned the building carefully. He says the university's options are limited, especially if the Theory Center is to be kept near the engineering campus. Keith Kennedy, chairman of the advisory board for Cornell Plantations which oversees the university's undeveloped property, believes the university has done the best job possible in locating the new building, but he expects the rest of his board will vote to reject the site chosen. The Ithaca city planning board has already considered and unanimously rejected it.

Joseph Palca 